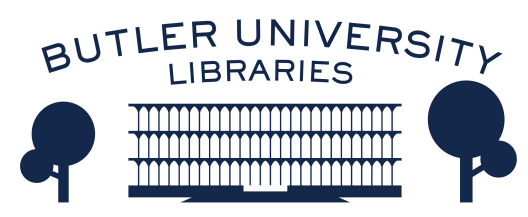

Journal of Hindu-Christian Studies

Volume 13

Article 20

January 2000

\title{
Book Review: "Dharma of the Twenty-first Century: Theological- Ethical Paradigm Shift"
}

Klaus K. Klostermaier

Follow this and additional works at: https://digitalcommons.butler.edu/jhcs

Part of the Religion Commons

\section{Recommended Citation}

Klostermaier, Klaus K. (2000) "Book Review: "Dharma of the Twenty-first Century: Theological-Ethical Paradigm Shift"," Journal of Hindu-Christian Studies: Vol. 13, Article 20.

Available at: https://doi.org/10.7825/2164-6279.1240

The Journal of Hindu-Christian Studies is a publication of the Society for Hindu-Christian Studies. The digital version is made available by Digital Commons @ Butler University. For questions about the Journal or the Society, please contact cbauman@butler.edu. For more information about Digital Commons @ Butler University, please contact digitalscholarship@butler.edu. 
and crucifixion of the divine being. Divine and human suffering is granted a spiritual significance in traditional Catholicism that is foreign to Hinduism, given the traditional emphasis on the uniqueness of the incarnation and the essential nature of Christ's redemptive suffering. So Siddheswarananda can speak provocatively of Ramakrishna's "non-Christian" experience of Christ in contrast with that of the Christian. Christian mystical experience requires "as an article of faith the dogmas and credo of the Church" (91).

In his critical reflections on these and other differences Swami Siddheswarananda illustrates how a detailed understanding of the doctrinal context of one's dialogue partner is crucial in fully appreciating her or his spiritual view. He also underscores the extent to which the socio-religious context of mystics enter into their experiences, thus insightfully prefiguring contemporary contextual views of mystical experience. Yet he seems a bit naive and inconsistent in the way in which he feels that certain Hindu mystics are somehow free of their doctrinal contexts, while Christian mystics remain constrained by theirs. Indeed, one wonders just where Siddheswarananda's own Hindu dogmas and credos enter into those core "extra-religious" experiences which provide for him the unifying ground of the various mystical traditions. Moreover, it remains unclear in his lectures just how those core Advaitic truths can provide, as he suggests, a coherent basis for bhakti yoga.

But the book should prove to be a remarkably interesting and helpful resource. It touches on a wide variety of issues and themes in quite thoughtful ways, including a notably eloquent comparative exploration of mystical love, as well as an intriguing analysis of the epistemological dynamics of different degrees of contemplation. William Buchanan has also included in his translation helpful glossaries of Sanskrit words, people, and sources, which adds to the book's appeal as a text in upper-level undergraduate or graduate seminars on comparative mysticism.

Michael Stoeber

Regis College, Toronto

\section{Dharma of the Twenty-first Century: Theological-Ethical Paradigm Shift. Somen Das. Calcutta: Punthi Pustak, 1996.}

DR SOMEN DAS, currently Principal of Bishops College in Calcutta, will already be known to many readers of the HinduChristian Studies Bulletin. He is the author of many books and articles that address the Christian presence in India. He also has had a distinguished academic career, having taught for many years at Serampore College and the United Theological College at Bangalore, before moving back to his native Calcutta.

The book under review contains his revised $\mathrm{PhD}$ thesis (University of Boston, 1977) and ten separate major articles that have appeared in various books and journals over the years. In a sense this represents the gathering of a lifetime of thinking and writing about Christianity and its relationship to
India.

This review cannot do justice to the richness and diversity of ideas offered in the book but will concentrate on those sections that deal directly with Hindu-Christian dialogue. The first five chapters - the revised $\mathrm{PhD}$ thesis - offer a thorough study of the notion of dharma as understood in the past and present in India. In a subsequent chapter, entitled "Towards a New Dharma: Dialogical Community Life" Somendas, after discussing the disruption of dialogical thought in India through the emergence of communalism and the disruption of dialogical thought and life in the world at large due to the monopoly of the ideology of the world market economy, offers constructive suggestions for building up a dialogical life 
from a biblical perspective. This is not, however, a naïve restatement of traditional biblical Christianity. One of the most trenchant chapters of the book is entitled " $\mathrm{A}$ Catalogue of Traditional Christian Spirituality". It examines and critiques what many would consider the sacred cows of Christianity, viz. the spirituality of the martyrs, of the ascetics, of the monastics, of the mystics, of the Pietists and Puritans, and finds that all these, while exhibiting some genuine aspects of the Christian ethos, fall short of what is required today. Somendas develops his own thoughts in a section "Spirituality in the Light of the New Dharma". Clearly inspired by the Hindu notion of dharma as a paradigm for theological-ethical innovation, he proceeds to reconstruct a contemporary Asian Christian spirituality from the New Testament and key Christian theological elements.

Somendas gives much room to pioneer
Asian theologians, such as Toyohiko Kagawa and C. S. Song, and characterizes the "New Christianity" emerging from contemporary Asian theology as "third-eye", i.e. inspired, and not just rational, as people's theology, i.e. not the domain of academics, as ecumenical and relevant, implicitly rejecting much of Western Christian theology as too abstract, purely denominational, and narrow-minded.

The book is thought-provoking, filled with flashes of insight and pithy observations. It should stimulate especially younger Asian Christians to developing a dialogical theology and ethic in their own homelands. For academic Christian theologians in Western countries, it may be an eye-opener.

Klaus K. Klostermaier

Oxford Centre for Vaisnava and Hindu Studies

\section{Asian Biblical Hermeneutics and Postcolonialism: Contesting} the Interpretations. R. S. Sugirtharajah. New York: Orbis Books, 1998, xii + 148pp.

COLONIALISM HAS PLAYED a significant role in the representation and interpretation of both Hindu and Christian religious traditions in India during and after the British rule in India. R. S. Sugirtharajah, a Sri Lankan theologian and a Senior Lecturer at Selly Oak Colleges in Birmingham, England, offers in this book a "resistant discourse which tries to write back and work against colonial assumptions, representations, and ideologies" ( $\mathrm{x}$ ). Here is a collection of essays that address the theme of postcolonial interpretation of the Bible. While some of the essays have already been published elsewhere, others are written specifically for this volume.

In Chapter 1, the author outlines the three prevalent modes of interpretation orientalist, anglicist, and nativistic - and offers a fourth option in his postcolonial criticism. The postcolonial option "involves the once-colonized 'Others' insisting on taking their place as historical subjects", offers a new identity to the interpreter, and unmasks "the link between ideas and power which lies behind Western texts, theories, and learning" (16ff.). Such an approach to the Bible looks for the "oppositional or protest voices within a text, refrains from romanticizing or idealizing the poor, refuses to blame the victims, and promotes "a wider hermeneutical agenda to place the study of sacred texts - Christian-Hindu, ChristianBuddhist, Christian-Confucian - within the intersecting histories which constitute them" (21-24). This chapter offers an excellent introduction to the whole project of the book. In the following chapters the author takes up some specific examples/events of textual interpretation and interprets them from the perspective of postcolonial criticism. For example, he analyses the 